\title{
Performa Kualitas Telur Ikan Gabus (Channa striata blkr) Dengan Pemberian Pakan Berbeda Dalam Wadah Terkontrol
}

\author{
Yulianty Adipu' ${ }^{1}$ dan Ahmad Rovik ${ }^{2}$ \\ ${ }^{1}$ Staf Pengajar Program Studi Perikanan dan Kelautan Universitas Gorontalo \\ E-mail : yuliantyadipu@rocketmail.com \\ 2 Balai Pengembangan Teknologi Budidaya Ikan Laut dan Payau Kabupaten \\ Boalemo
}

\begin{abstract}
This study aims to determine the management techniques of snakehead fish in the spawning process conducted in a controlled container and to know the performance of egg quality of snakehead fish. The experimental method was done experimentally by using a complete randomized design (RAL) with three feeding treatments and three replications, the treatment consisted of treatment $A$ using 38\% artificial protein, B treatment using rucah (fresh fish), and $C$ treatment using mascot. The test animal used is the snake head totaling 49 tail, with the size of weight 350 grams up to 800 grams. The variables observed in this research consist of fecundity, hatchability, survival rate and water quality. The feed treatment A (golden snail) resulted in the highest number of eggs (fecundity) 5928 grains, followed by treatment $B$ (feed trash) that is 4360 grains, and treatment A (pellet feed) ie 4134 grains. The result of hatching rate analysis at the highest treatment $A$ reached $92,10 \%$, in treatment $B$ hatching degree was obtained $71,42 \%$, while at treatment $C$ obtained $56,60 \%$. The observation variable for seed survival rate in treatment $A$ resulted in 4367 head, whereas at treatment $B$ obtained larvae 2245 tail, and at treatment C obtained 1450 tail. Based on the results of the research I can conclude that with different did not give a real effect on the number of eggs, hatchability and survival rate in snake head. While for water quality measurement obtained temperature value around $27-32^{\circ} \mathrm{C}$, brightness $30-40 \mathrm{~cm}$, oxygen and $\mathrm{pH}$ at normal value 7 .
\end{abstract}

Keywords : Quality eggs, snakehead fish, Feed 


\section{Pendahuluan}

Ikan Gabus (Channa striata blkr) merupakan salah satu komoditas air tawar yang mempunyai nilai ekonomis tinggi yang keberadaannya semakin berkurang. Melihat potensi yang dimiliki ikan Gabus cukup besar yang diantaranya kaya akan khasiat untuk obat berbagai jenis penyakit. Berdasarkan hasil penelitian ikan Gabus mengandung albumin yang mempunyai banyak gugus sulfhidril (-SH) yang dapat berfungsi sebagai pengikat radikal. Protein yang kaya akan gugus - SH akan mampu mengikat logam-logam berbahaya dan juga senyawa-senyawa yang bersifat efek sntioksidan, dan asam sialik (Kusumaningrum, 2013). Ikan gabus yang ditanggap di alam sebagian besar berukuran kurang dari $30 \mathrm{~cm}$ bahkan yang berukuran 50 cm sudah jarang (Makmur, 2013). Selain karena kerusakan habitat banyaknya permintaan ikan gabus menyebabkan terjadinya eksploitasi ikan tersebut secara berlebihan, hal ini dikhawatirkan dapat menyebabkan populasi ikan gabus di alam semakin berkurang.

Budidaya ikan gabus belum banyak mendapats perhatian disebabkan masih minimnya informasi teknologi budidaya. Penerapan teknologi budidaya ikan gabus dimasyarakat masih menjadi salah satu kendala ketersedian benih, baik secara kualitas maupun kuantitas.

Dalam rangka pengembangan budidaya ikan gabus telah banyak dilakukan penelitian mengenai ikan tersebut, mulai dari pembenihan sampai dengan pembesaran. Hasil penelitian Muslim dan Syaifudin (2012), tentang domestikasi ikan gabus telah menunjukkan hasil yang menggembirakan dimana kelangsungan hidup yang diperoleh mencapai 90 \%. Selain itu menurut Kordi (2011), Balai Budidaya Air Tawar (BBAT) Mandiangin Kalimantan Selatan telah berhasil dalam hal pembenihan ikan gabus. Namun demikian meskipun pengembangan ikan gabus sudah berhasil dilakukan tetapi permasalahan yang dihadapi adalah masih rendahnya kelangsungan hidup pada fase larva (Ramli dan Rifa'i, 2010). Untuk itu perlu dilakukan suatu upaya agar dapat meningkatkan kelangsungan hidup larva ikan gabus.

Penelitian ini bertujuan untuk untuk mengetahui manajemen induk ikan gabus yang dipersiapkan untuk pemijahan dan mengetahui performa kualitas telur induk ikan Gabus (Channa striata blkr) yang diberi pakan berbeda dalam wadah terkontrol.

\section{Metode Penelitian}

Penelitian ini dilakukan di unit pembenihan rakyat yang melakukan produksi pembenihan ikan air tawar dan telah memperoleh sertifikat CPIB yang dilaksanakan selama 4 bulan yang dimulai dari bulan januari sampai april tahun 2017.

Metode penelitian dilakukan secara eksperimental dengan menggunakan rancangan acak lengkap (RAL) dengan empat perlakuan dan tiga kali ulangan. Adapun perlakuan dalam penelitian ini terdiri dari : Perlakuan $\mathrm{A}=$ pemberian pakan buatan protein $38 \%$, Perlakuan B = pemberian pakan rucah (Ikan Segar), perlakuan 
$\mathrm{C}=$ pemberian pakan dengan menggunakan keong mas, perlakuan $\mathrm{D}=$ Kontrol (dengan menggunakan benih ikan) dengan 3 kali ulangan secara keseluruhan.

Adapun induk ikan gabus yang digunakan yang berasal dari Danau Santigi

Desa Santigi Kecamatan Bolano Lambunu Kabupaten Parigi Moutung Provinsi Sulawesi Tengah. Setiap perlakuan induk ikan jantan dan betina yang digunakan berpasangan berukuran panjang $30-35 \mathrm{~cm}$ dengan berat induk berkisar antara 350 gram sampai dengan 780 gram sebanyak 49 ekor yang sebelumnya telah di aklimatisasi selama satu bulan di lokasi penelitian. Pemeliharaan induk ikan dilakukan pada bak beton kemudian diberi waring waring hitam dengan ukuran $\mathrm{P}$ x L x T yaitu $1,5 \times 1,5 \times 1,2 \mathrm{~m}^{3}$ berjumlah 12 buah yang diberi label dan dilengkapi aerasi selama pemeliharaan. Pemberian pakan menggunakan pakan terapung PF 128 dengan kandungan protein 38\%, ikan rucah dan keong mas dengan dosis yang diberikan 3\% dari total biomassa induk yang diberikan 2 kali sehari. Parameter kualitas diukur meliputi suhu, kecerahan, oksigen, $\mathrm{pH}$, dan amonia yang diukur pada awal, pertengahan dan akhir penelitian

Pemijahan ikan gabus yang dilakukan dalam penelitian ini adalah dengan sistem pemijahan alami, ikan gabus yang sudah memenuhi kriteria siap pijah secara morfologi dipasangkan dalam waring hitam yang ditempatkan bak beton. Pemijahan ikan gabus terjadi pada saat malam hari dan telur yang dipijahkan bersifat mengapung pada permukaan air. Pemijahan alami induk ikan gabus dilakukan dengan melihat ciri ciri visual induk jantan dan betina yang telah matang gonad, kemudian induk yang matang gonad dilakukan pemasangan pada tiap tiap wadah perlakuan dengan cara memasukan induk jantan dan betina dengan ratio (perbandingan) antara induk jantan dan betina adalah 1:1. Selanjutnya ditambahkan tanaman air kankung air untuk tempat berlindung bagi induk serta sebagai media berlindungnya telur ikan gabus. Setiap hari dilakukan pemeriksaan pada bak pemijahan.

Manajemen larva ikan gabus mulai dari awal penetasan sampai berumur 15 hari. Pemberian pakan larva mulai diberikan pakan mulai umur 3 hari dengan mengunakan pakan alami artemia, dapnia serta pakan buatan. Larva ikan gabus (channa striata) dilakukan pengamatan tingkat kehidupan (surfive rate) hingga berusia 15 hari.

Variabel yang diamati dalam kegiatan penelitian ini adalah manajemen induk dengan metode deskripsi, fekunditas dan daya tetas dan tingkat kelangsungan hidup pada ikan gabus (channa striata blkr) yang diberi pakan dengan jenis berbeda diamati menggunakan beberapa rumus antara lain :

Jumlah Telur (Fekunditas), Daya tetas (DT), Kelangsungan hidup (survife rate) dihitung menggunakan menggunakan rumus Efendi, et al, 2006 sebagai berikut :

$$
\text { JumlahTelur }=\frac{\text { Jumlahtelurdalamvolumeairsampel }}{\text { Jumlahairsampel }} \times \text { Volumeair }
$$




$$
\begin{gathered}
\text { DayaTetas }=\frac{\text { Jumlahtelurmenetas }}{\text { Jumlahtelurfertil }} \times 100 \\
S R=\frac{N t}{N o} X 100
\end{gathered}
$$

Ket : SR $=$ Tingkat kelangsungan hidup (\%)

$\mathrm{Nt}=$ Jumlah ikan hidup pada akhir pemeliharaan (ekor)

No $=$ Jumlah ikan awal pada pemeliharaan (ekor)

Sebagai data penunjang, dilakukan pengukuran beberapa pameter kualitas air yaitu suhu, oksigen terlarut dan $\mathrm{pH}$. Seluruh data penelitian ditabulasi dan dianalisis dengan menggunakan program SPSS.

\section{Hasil Dan Pembahasan}

\subsection{Jumlah Telur (Fekunditas)}

Fekunditas ikan Gabus yang diamati pada penelitian terlihat bahwa jumlah telur pada perlakuan pemberian pakan buatan lebih kecil dari pada jumlah pada pemberian pakan rucah dan pakan keong mas, pada perlakuan pemberian pakan buatan jumlah telur yang diperoleh 4134 butir, pada pemberian pakan rucah jumlah telur yang diperoleh 4368 sedangkan pada perlakuan pemberian pakan keong mas diperoleh jumlah telur 5928. Untuk lebih jelas dapat dilihat pada gambar 1 .

Berdasarkan dari jumlah telur yang ada perbedaan selisih antara jumlah telur ikan gabus yang diberi pakan keong mas dengan pakan rucah 1560 butir, sedangkan pada perlakuan pemberian pakan keong mas dengan pakan pelet perbedaan selisih jumlah telur yang dihasilkan 1794 butir dan pada perlakuan pemberian pakan rucah dengan pakan pelet tidak berbeda jauh yaitu 234 butir.

Telur merupakan hasil akhir dari proses gametogenesis, setelah oosit mengalami fase pertumbuhan yang panjang dan tergantung pada gonadotropin. Perkembangan diameter telur pada umumnya disebabkan karena akumulasi kuning telur selama proses vitolegenesis (Hariyano., at al, 2013). Menurut Harianti (2012), fekunditas ikan gabus (Channa striata) berkisar antara $1062-57200$ butir telur pada kisaran bobot tubuh 181.80 gram-500.00 gram. Tidak selamanya ikan yang mempunyai bobot maksimal memiliki fekunditas yang banyak. Hal ini diduga karena bobot tubuh menigkat disebabkan oleh bobot lambung yang besar sedangkan bobot gonadnya kecil, sehingga fekunditas pada bobot tersebut kurang. 


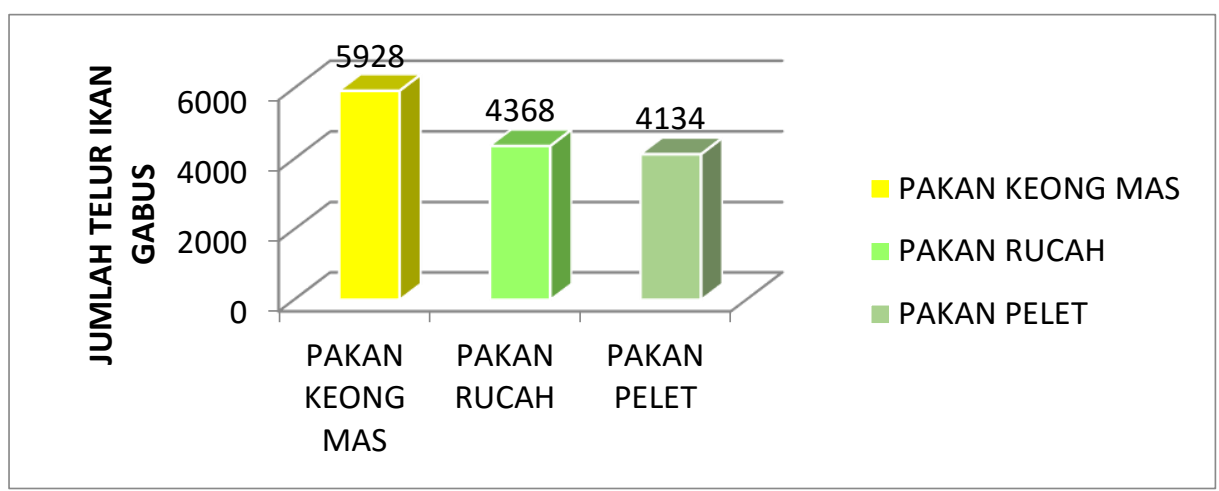

Gambar 1. Jumlah Telur ikan gabus

Menurut Makmur dalam hariyati (2012), di perairan alam waduk Kedungombo 24 induk menghasilkan fekunditasnya berkisar antara 2585-12880 butir telur pada bobot tubuh antara 60-1020 gram sedangkan di daerah aliran sungai Musi induk ikan gabus yang mempunyai bobot tubuh antara 60-640 gram memiliki fekunditas antara 1141 butir - 16480 butir. Hal ini diduga karena adanya perbedaan faktor lingkugan yang menyangkut persedian makanan. Selain itu juga dipengaruhi oleh segar tidaknya ikan pada saat penimbangan bobot ikan. Ikan yang telah menurun tingkat kesegaranya akan menurunkan bobot tubuhnya

Berdasarkan hasil analisis ragam pemberian pakan berbeda pada ikan gabus tidak memberikan pengaruh yang nyata terhadap jumlah telur (fekunditas) yang dihasilkan. Hal ini karena nilai F Hitung yang diperoleh lebih kecil dari nilai F Tabel pada taraf $5 \%$ maupun taraf $1 \%$, dengan demikian tidak dilanjutkan dengan uji lanjut.

\subsection{Derajat Penetasan (hatching rate)}

Berdasarkan dari hasil data penelitian jumlah tingkat penetasan pada masing masing perlakuan diperoleh data yang berbeda beda (Gambar 2). Hasil dari perhitungan sampling penetasan pada telu ikan gabus pada perlakuan pemberian pakan keong mas mencapai 92,10\% , sedangkan pada perlakuan pada pemberian pakan rucah diperoleh penetasan $71,42 \%$ sedangkan pada perlakluan pemberian pakan pellet diperoleh tingkat penetasan 56,60\%. Menurut Hariyano., et al (2013), derajat penetasan merupakan faktor penting dalam kegiatan perbenihan., derajat penetasan yang tinggi dapat menghasilkan yang banyak sehinga proses produksi dapat berjalan dengan baik. Derajat penetasa dipengaruhi oleh beberapa factor seperti pakan induk yang digunakan, kualitas induk, suhu, $\mathrm{pH}$, air media dan intensitas cahaya. Telur ikan ikan gabus berbentuk lonjong, transparan. Ukurannya sangat kecil, kira-kira hanya bergaris tengah $0,83 \mathrm{~mm}$. Telur tersebut melekat pada dinding sarang. Setelah kontak dengan air selama 10-15 menit, membran vitelinya akan mengembang terns dan panjang telur meningkat sekitar $50 \%$ hingga telur berukuran 1,3 $\mathrm{mm}$. 


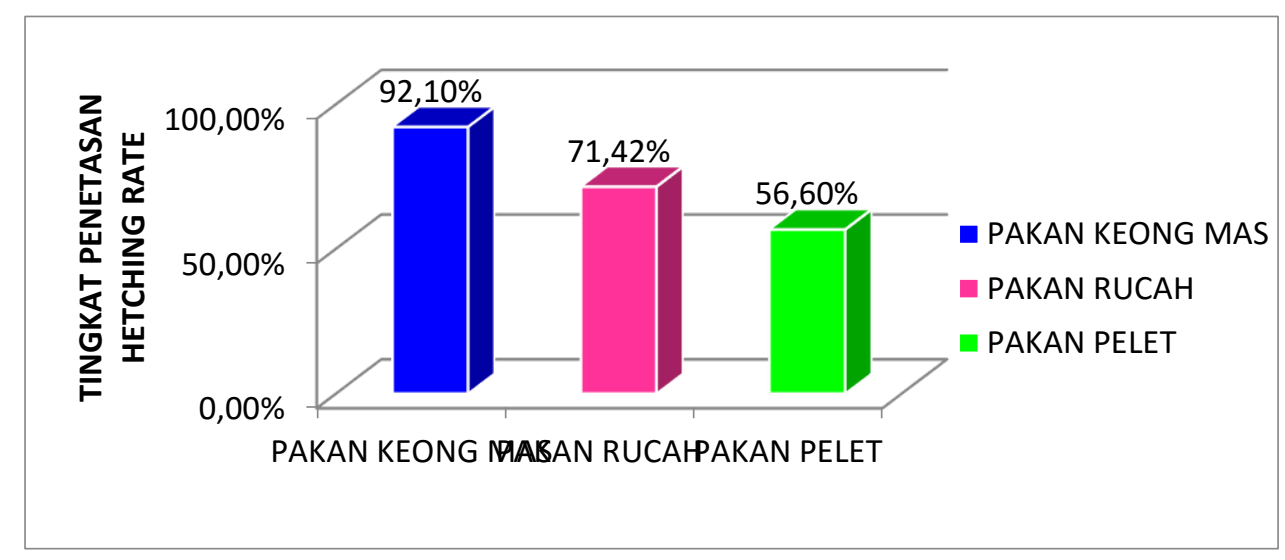

Gambar 2. Tingkat Derajat Penetasan (Hatching rate)

Berdasarkan dari data yang diperoleh dapat kita simpulkan bahwa pada perlakuan pemberian pakan keong mas dengan membandingkan pakan rucah terjadi perbedaan tingkat penetasan $20,68 \%$, sedangkan pada perlakuan pemberian pakan rucah dengan pakan pelet terjadi perbedaan derajat penetasan $14,82 \%$. Perbedaan perlakuan yang sangat berpengaruh nyata adalah pemberian pakan keong mas dengan pakan pelet, hal tersebut ditunjukan dengan tingkta perbedaan derajat penetasan 35,5\%.

Menurut KKP (2014), hasil pengamatan fekunditas yang dilakukan dengan cara membedah dan menghitung jumlah total telur diperoleh jumlah telur antara 8.14010.085 butir dengan bobot induk betina berkisar antara 270-360 gram / ekor. Dari hasil derajat penghitungan derajat pembuahan telur ikan gabus tergolong baik berkisar antara $75-93 \%$ sedangkan derajat penetasan telur ikan masih tergolong rendah antara $41-83 \%$.

Berdasarkan hasil analisis ragam bahwa pemberian pakan berbeda pada ikan gabus tidak memberikan pengaruh yang nyata terhadap tingkat penetasan (Hatching Rate) telur. Hal ini karena nilai F Hitung yang diperoleh lebih kecil dari nilai F Tabel pada taraf $5 \%$ maupun taraf $1 \%$, dengan demikian tidak dilanjutkan dengan uji lanjut.

\subsection{Tingkat Kelangsungan Hidup (SR)}

Berdasarkan pengamatan larva ikan gabus mulai berubah warna morfologi tubuh mencapai usia 15 hari. Perubahan kondisi tersebut dapat dipengaruhi berdasarkan aspek internal maupun eksternal. Pada saat pemeliharaan larva manajemen kualitas air harus dilakukan guna menjaga kondisi air agar tetap baik. Berikut ini adalah gambar kelangsungan hidup larva ikan gabus hingga benih mencapai umur 45 hari (Gambar 3). 


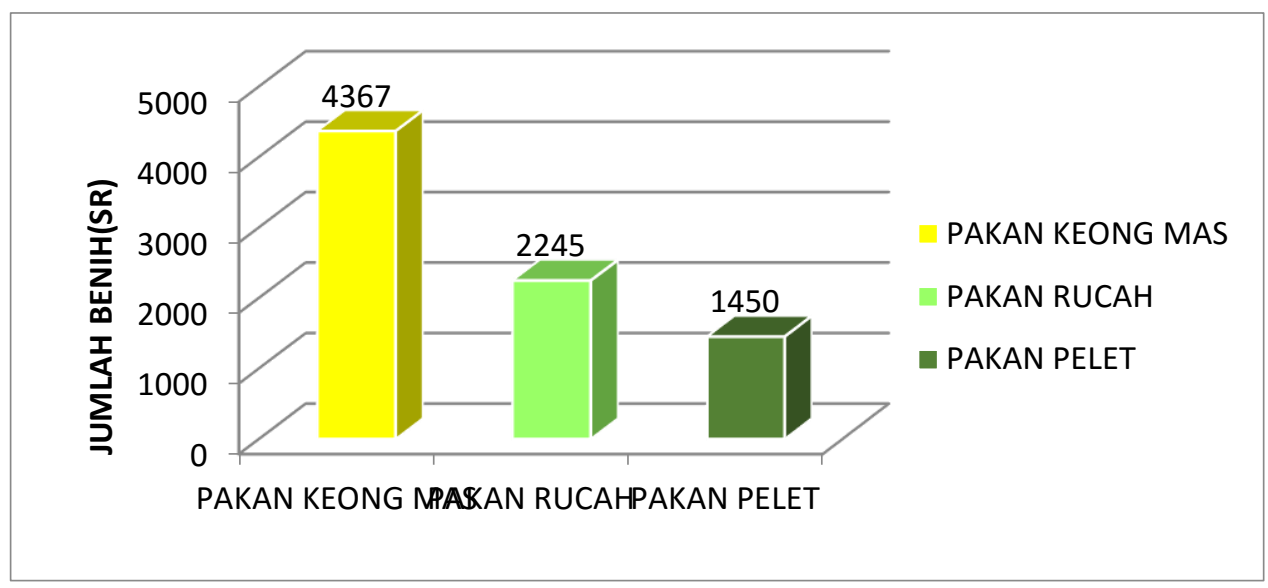

Gambar 3. Tingkat Kelangsungan Hidup Larva Ikan Gabus

Berdasarkan nilai grafik yang ada bahwa perlakuan pemberian pakan pada manajemen induk ikan gabus memberikan nilai paling tinggi yaitu sebesar 4367 ekor pada pakan menggunakan keong mas dengan tingkat keberhasilan $80 \%$. Hal serupa juga berlaku pada hasil penelitian yang dilakukan pada pemeliharaan induk ikan patin (Pangasius sp.) Menurut Abdullah (2000), dengan bahan pakan keong mas memberikan hasil yang cukup baik bagi pertumbuhan ikan. Pada budi daya ikan nila (Orochromis niloticus) komposisi 50\% tepung ikan dan 50\% telung keong mas memberikan pertumbuhan yang cukup baik, dengan nilai konversi pakan yang rendah. Selain itu, pakan yang dibuat dari keong mas juga telah dilakukan pada pemeliharaan ikan sidat serta pakan ikan mas dapat diperoleh sekitar $170 \mathrm{~kg}$ tepung keong mas/minggu (Kordi et al, 2011).

Pada pakan rucah diperoleh tingkat kelangsungan hidup benih ikan gabus $72 \%$ dengan jumlah benih 2245 ekor sedangkan pakan pellet diperoleh tingkat kelangsungan hidup benih ikan gabus hanya 62\% dengan jumlah 1450 benih. Rendahnya kelangsungan hidup larva ikan gabus diakibatkan terjadinya persaingan antara individu ikan dalam hal memperebutkan ruang gerak dan makan. Pada kepadatan yang tinggi akan terjadi pertumbuhan yang beragam yang mengakibatkan persaingan dalam hal mendapatkan makanan meskipun jumlah pakan yang diberikan cukup terpenuhi. Larva yang ukuran lebih besar akan lebih menguasai makanan sehingga ukuran larva yang kecil akan kalah dalam memperebutkan pakan yang diberikan (Syarif . at al, 2014).

Menurut Yulisma (2011) Pertumbuhan dan kelangsungan hidup ikan dapat dipengaruhi oleh beberapa faktor, diantaranya kualitas dan kuantitas pakan yang diberikan selama pemeliharaan. Pakan alami yang diberikan merupakan jenis artemia dengan jumlah pemberian 5-8 individu / $\mathrm{ml}$ sebanyak 3 kali pemberian. Pakan alami artemia diberikan sampai umur larva ikan gabus mencapai 10 hari, selanjutnya pakan alami yang diberikan kutu air, dapnia, sesuai bukaan mulut larva ikan. Pakan alami merupakan sumber sebagai sumber nutrisi mikro dan 
makro serta menghasilkan enzim untuk menigkatkan pencernaan yang dibutuhkan oleh sebagian besar oleh larva ikan (Hartini et al, 2013)

Frekuensi pemberian pakan selama pemeliharaan sebanyak tiga kali sehari pukul 08.00 WITA, siang hari pukul 12.00 WITA dan sore hari pada pukul 16.00 WITA di tempat pemeliharaan. Hal tersebut ditunjang dengan pernyataan Hidayat et al. (2013) menyatakan selama pemeliharaan benih ikan gabus diberi pakan secara at satiation (diberi makan hingga kenyang).

Berdasarkan hasil analisis ragam menunjukkan bahwa pemberian pakan berbeda pada ikan gabus tidak memberikan pengaruh yang nyata terhadap tingkat kelangsungan hidup (Survival Rate) larva. Hal ini karena nilai F Hitung yang diperoleh lebih kecil dari nilai $\mathrm{F}$ Tabel pada taraf $5 \%$ maupun taraf $1 \%$, dengan demikian tidak dilanjutkan dengan uji lanjut.

\subsection{Kualitas Air}

Sumber air yang digunakan pada proses pemeliharaan induk, pemijahan, penetasan telur, pemeliharaan larva. Sumber air tersebut berasal dari air kolam tanah yang dipompa dengan mengunakan pompa dap, yang disalurkan melalui instalasi pipa inlet menuju bak tandon (bak penampungan air). Hasil pengukuran kualitas air di Daseng Farm dapat dilihat pada tabel 1.

\section{Tabel 1. Parameter kualitas air di UPR Daseng Farm Kota Gorontalo}

\begin{tabular}{lccccc}
\hline - & $\begin{array}{c}\text { Parameter } \\
\text { Kualitas Air }\end{array}$ & $\begin{array}{c}\text { Hasil } \\
\text { Pengukuran } \\
\text { Awal }\end{array}$ & $\begin{array}{c}\text { Hasil } \\
\text { Pengukuran } \\
\text { Tengah }\end{array}$ & $\begin{array}{c}\text { Hasil } \\
\text { Pengukuran } \\
\text { Akhir }\end{array}$ & Keterangan \\
\hline 1 & Suhu ${ }^{\circ} \mathrm{C}$ & $27-31{ }^{\circ} \mathrm{C}$ & $28-31{ }^{\circ} \mathrm{C}$ & $28-32{ }^{\circ} \mathrm{C}$ & Termometer \\
2 & Kecerahan & $30 \mathrm{~cm}-40 \mathrm{~cm}$ & $35 \mathrm{~cm}-40 \mathrm{~cm}$ & $35 \mathrm{~cm}-40 \mathrm{~cm}$ & Secsidisk \\
3 & Oksigen & $5-7$ & $5-7$ & $5-7$ & DO Meter \\
4 & pH air & $7-8$ & $7-8$ & $7-8$ & pH Meter \\
\hline
\end{tabular}

Menurut Muslim (2012) Salah satu faktor yang mempengaruhi kelangsungan hidup ikan yang didomestifikasi adalah kualitas air. Hasil pengukuran parameter kualitas air dalam kolam pemeliharaan ikan gabus suhu berkisar $25-30^{\circ} \mathrm{c}$, keasaman air berkisar 6-7 serta oksigen terlarut berkisar 4,2-4,5 ppm. Kondisi kualitas air ini masih

dalam toleransi untuk mendukung kehidupan ikan gabus yang dipelihara.

Ikan Gabus termasuk salah satu jenis ikan yang mempu mempertahankan hidupnya dalam kondisi lingkungan dengan kadar oksigen rendah. Pada penelitian untuk kadar oksigen air dalam kolam sudah mencukupi kebutuhan ikan gabus. Ikan gabus mampu memanfaatkan oksigen dari atmosfer untuk proses pernafasanya dengan mengunakan alat bantu pernafasan / breating organ (Chandra dan Tanun,2004 dalam Muslim , 2012). 


\section{Kesimpulan}

Pemberian jenis pakan yang berbeda tidak berpengaruh nyata terhadap jumlah telur, derajat penetasan dan kelangsungan hidup benih ikan Gabus. Berdasarkan hasil data yang diperoleh bahwa dengan penggunaan pakan keong mas diperoleh jumlah telur tertinggi sebanyak 5.928 butir dengan tingkat penetasan $92,10 \%$ dan kelangsungan hidup benih sebanyak 80\% atau 4.367 ekor benih ikan gabus. Kualitas air selama penelitian masih dalam kisaran yang layak untuk pertumbuhan dan kelangsungan hidup benih ikan Gabus.

\section{Daftar Pustaka}

Hariyono, Marwan, Narulita, Ely, dan Kalasuma Tuan kotta, 2013 " Pengaruh Dosis berbeda Terhadap Kualitas Induk Mandarin Fish(Synchiropus Splendidus " Balai Budidaya Laut Ambon

Hariati, 2012. Fekunditas dan Diameter Telur Ikan Gabus (Channa striata Bloch) di Danau Tempe, Kabupaten Wajo, Skripsi, Jurusan Perikanan, Sekolah Tinggi Teknologi Kelautan, (STITEK) Balik Diwa, Makasar

Hidayat Deny, Sasanti dwi ade, Yulisman, 2013, Kelangsungan Hidup, Pertumbuhan dan efisiensi Pakan Ikan Gabus (Channa striata) yang diberi pakan berbahan baku tepung Keong Mas (Pomacea sp), Program Studi Budidaya Perairan Fakultas Pertanian Universitas Sriwijaya, Indralaya, Ogan illir 30662

Kementrian Kelautan dan Perikanan, 2014, Budidaya Ikan Gabus Haruan (Channa striata bloch), Direktorat Jenderal Perikanan Budidaya, Balai Budidaya Air Tawar Mandiangin

Kordi, K. M.G.H. 2011. Panduan Lengkap Bisnis dan Budidaya Ikan Gabus. Lily Publisher. Yogyakarta.

Kusumaningrum Galuh Ajeng. 2013. Uji Kadar Albumin Dan Pertumbuhan Ikan Gabus (Channa striata) Dengan Kadar Protein Pakan Komersialyang Berbeda. Universitas Airlangga

Makmur, S. 2003. Biologi reproduksi, makanan dan pertumbuhan ikan gabus (Channa striata Bloch) di daerah banjiran Sungai Musi, Sumatra Selatan. Tesis. Program Pascasarjana. Institut Pertanian Bogor. Bogor.

Muslim, dan Syifudin ,M. 2012. Domestifikasi calon induk ikan gabus (channa striata) dalam lingkungan budidaya (kolam beton) Majalah Ilmiah Sriwijaya 21(15): 20-27 
Ramli HR dan Rifa'i MA. 2010. Telaah Food Habits, Parasit, dan Bio-Limnologi Fasefase Kehidupan Ikan Gabus (Channa striata) di Perairan Umum Kalimantan Selatan. Ecosystem. 2 (10) : 76-84.

Yulisman, M. Fitriani, D. Jubaedah. 2012. Peningkatan pertumbuhan dan efiesien pakan ikan gabus (Channa striata) melalui optimasi kandungan protein dalam pakan. Berkala Perikanan Terubus 40(2): 47-55. 